\title{
Growth, Yield and Nitrogen Use Efficiency in Wheat as Influenced by Leaf Colour Chart and Chlorophyll Meter Based Nitrogen Management
}

\author{
Reena*, V.C. Dhyani, Sumit Chaturvedi and Himansu Sekhar Gouda
}

Department of Agronomy, G.B. Pant University of Agriculture and Technology, Pantnagar, Uttarakhand- 263145, India

*Corresponding author

\section{A B S T R A C T}

\section{Keywords}

Agronomic efficiency, Chlorophyll meter (SPAD meter), Grain yield, Growth, Leaf Colour Chart (LCC), Recovery efficiency, Total nitrogen uptake, Wheat.

\section{Article Info}

Accepted:

15 October 2017

Available Online:

10 December 2017
Field experiment was conducted at G.B. Pant University of Agriculture and Technology, Pantnagar, Uttarkahand, during the winter (rabi) season of 2014-15.The study aimed to investigate the effect of leaf colour chart (LCC) and chlorophyll meter (SPAD meter) based nitrogen management on wheat crop. Application of nitrogen at lower rate of $105 \mathrm{~kg}$ /ha based on LCC value (4 and 5) and SPAD (30 and 40) resulted statistically similar growth, yield attributes viz., plant height, shoot density, dry matter, leaf area index, number of grains per spike and 1000 grains weight compared with recommended practice $(150 \mathrm{~kg} / \mathrm{ha})$ in turns resulted into at par grain yield but significantly superior over LCC and SPAD based treatment of $85 \mathrm{~kg} \mathrm{~N} / \mathrm{ha}$ and control treatment. Similar trend was observed in physiological parameters viz., chlorophyll content, chlorophyll meters reading (SPAD value), efficiency of photosystem II (Fv/Fm) and total nitrogen uptake. Higher numerical value of nitrogen use efficiency in terms of agronomic efficiency, recovery efficiency obtained from LCC and SPAD based treatments of $105 \mathrm{~kg} / \mathrm{ha}$ than recommended nitrogen management. Thus study concluded that LCC and SPAD are the effective tools which help to uptake applied nitrogen more efficiently rather than subjected to losses and make more economic use of absorbed nitrogen with the saving of 30 per cent or $45 \mathrm{~kg} / \mathrm{ha}$ nitrogen without any significant yield decrement.

\section{Introduction}

Nitrogen is the most important limiting factor determining the yield of wheat. An appropriate level of nitrogen is necessary for good crop production because nitrogen is constituent of protoplasm, protein, chlorophyll, alkaloids, hormones and vitamins. Nitrogen increases dry matter production and ultimately results in more yields. Among various production inputs, nitrogen fertilizers have played a key role in increasing production of wheat in India since 1960. To achieve high yields of wheat, farmers in many parts of the world tends to apply nitrogen (N) in excess of the requirements. This is particularly true in the wheat-growing area of the Indo-Gangetic Plains (IGP) leads to reduction in $\mathrm{N}$ fertilizer recovery efficiency which is already no more than 50 percent (Singh et al., 2001). A recent world-wide evaluation shows that the fertilizer $\mathrm{N}$ recovery efficiency is around 30 per cent in wheat with current practices (Krupnik et al., 2004). The major reason of low N-use efficiency is fixed-time splitting of 
$\mathrm{N}$ applications advocated in current recommendation or $\mathrm{N}$ application is not synchronized with crop demand, as well as the use of nitrogen in excess to the requirement. On the other side nitrogen is also subject to various kinds of losses viz. denitrification, volatilization and leaching resulting in poor nitrogen use efficiencies.

The real time nitrogen management approach can help increase nitrogen use efficiency by matching time of fertilizer application with plant need. Some Modern gadgets or tools like Leaf colour chart (LCC) based on spectral properties of leaf and chlorophyll meter or Soil Plant Analysis Determination (SPAD) meter based on light transmittance through leaves has been reported by several researchers as reliable tools to increase $\mathrm{N}$ use efficiency in rice and wheat. They regulate the timing of nitrogen application (Singh et al., 2002). The concept is based on the result that show close link between leaf chlorophyll and nitrogen content. SPAD and LCC can save up to 50 and $60 \mathrm{~kg} \mathrm{~N} / \mathrm{ha}$, respectively, without yield decrement in wheat over the fixed timing $\mathrm{N}$ treatments where $150 \mathrm{~kg} \mathrm{~N} / \mathrm{ha}$ was applied in 3 Splits (Maiti and Das, 2006). Thus Nitrogen management through LCC and SPAD can be an effective strategy for improving the $\mathrm{N}$ efficiency and minimizing the losses. Research study carried out with the hypothesis to see whether different nitrogen fertilization based on some threshold values of leaf colour chart (LCC) and chlorophyll meter (SPAD meter) utilized nitrogen more efficiently or not over recommended practice of nitrogen management. Aim was also to find out the effect on growth, yield and physiological parameters.

\section{Materials and Methods}

The field experiment was conducted at Crop research center of Govind Ballabh Pant University of Agriculture and Technology,
Pantnagar, Uttarakhand during the rabi season of 2014-15. Pantnagar is located at $29^{\circ} \mathrm{N}$ latitude, $79.29^{\circ} \mathrm{E}$ longitude and an altitude of $243.84 \mathrm{~m}$ above the mean sea level in the tarai belt of Shiwalik range of the Himalayan foot hills. It falls under the subhumid and sub-tropical climatic zone. The experiment site had silty clay loam soil and Mollisol in nature. Soil of the experimental plot was high in organic carbon (0.66 per cent), low in available nitrogen $(234 \mathrm{~kg} / \mathrm{ha})$, medium in available phosphorus $(24 \mathrm{~kg} / \mathrm{ha})$, medium in available potassium $(187 \mathrm{~kg} / \mathrm{ha})$ and $\mathrm{pH}$ near to neutral in reaction (7.2). The experiment was laid out in randomized block design comprising 12 treatments with 3 replications. Different nitrogen management treatments comprising of control (no $\mathrm{N}$ ), recommended $\mathrm{N}(50 \mathrm{~kg} / \mathrm{ha}$ as basal +50 $\mathrm{kg} / \mathrm{ha}$ at crown root initiation $+50 \mathrm{~kg} / \mathrm{ha}$ at maximum tillering), $25 \mathrm{~kg} / \mathrm{ha}$ as basal + two splits of $30 \mathrm{~kg} \mathrm{~N} / \mathrm{ha}$ (at LCC 4, 5 and SPAD $35,40), 25 \mathrm{~kg} / \mathrm{ha}$ as basal + two splits of 40 $\mathrm{kg} / \mathrm{ha}$ (at LCC 4,5 and SPAD 35, 40), 25 $\mathrm{kg} / \mathrm{ha}$ as basal $+30 \mathrm{~kg} / \mathrm{ha}$ at CRI + one split of $30 \mathrm{~kg} \mathrm{~N} / \mathrm{ha}$ at SPAD 40 and $25 \mathrm{~kg} / \mathrm{ha}$ as basal $+40 \mathrm{~kg} / \mathrm{ha}$ at CRI + one split of $40 \mathrm{~kg} \mathrm{~N} / \mathrm{ha}$ at SPAD 40.

Variety HD 2967 was sown on 14 November, 2014 using seed rate of $100 \mathrm{~kg} / \mathrm{ha}$ and spacing $20 \mathrm{~cm}$. Fertilizer application was done as per the treatments in the individual plots.NPK mixture, urea, SSP, MOP were used as the source of N, P and $\mathrm{K}$ respectively. The full amount of phosphorus $60 \mathrm{~kg} / \mathrm{ha}$ and potassium $40 \mathrm{~kg} / \mathrm{ha}$ applied as basal while nitrogen was applied as per the treatments. SPAD meter and LCC were used for measurement of 10 topmost fully expended leaves at 7 days interval at a specified time and averaged for each plot. Composite plant samples (grain and straw) were used for each treatment at harvest for analyzing nitrogen. Nitrogen content in plant was determined by micro Kjeldahl's method (Jackson, 1958). 
The total nitrogen uptake was calculated by multiplying nitrogen concentration in the tissue of the plant to grain and straw yield. Nitrogen use efficiency in terms of agronomic efficiency ( $\mathrm{kg}$ grain yield increase per $\mathrm{kg} \mathrm{N}$ applied) and recovery efficiency (increased nitrogen uptake per kg nitrogen applied) were calculated by using the formula (Cassman et al., 1998) given below:

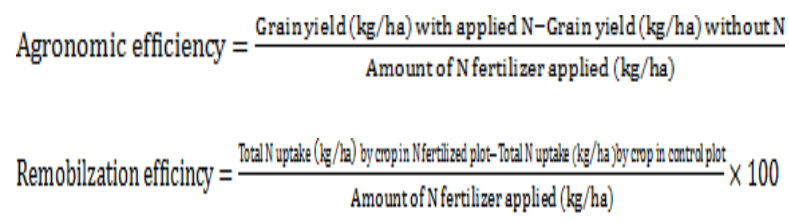

All the data for wheat were pooled statistically and then data were statistically analysed with the help of statistical programme STPR-3 of Department of mathematics, statistics and Computer Sciences, Pantnagar.

\section{Results and Discussion}

The trends of all the growth parameters viz., plant height, shoot density, dry matter, leaf area index (LAI) at 60 and 90 days after sowing revealed that all the nitrogen management treatments had significant influence over control. Maximum value of aforesaid parameters were recorded in recommended nitrogen management i.e., 150 $\mathrm{kg} \mathrm{N} /$ ha (Table 1); however, they were at par with real time nitrogen management at lower rate of $105 \mathrm{~kg}$ /ha based on LCC value (4 and 5) and SPAD (30 and 40) including application of $\mathrm{N}$ as $25 \mathrm{~kg}$ as basal and two times application of $40 \mathrm{~kg}$ (at LCC 4, 5 and SPAD 35, 40) and $25 \mathrm{~kg}$ as basal $+40 \mathrm{~kg}$ at CRI $+40 \mathrm{~kg}$ at SPAD 40. This might be because of nitrogen application based on LCC and SPAD was done as per the crop need rather than at fixed time. This caused favourable effect of $\mathrm{N}$ on cell-division and tissue organization that ultimately improved plant height, tiller formation and dry-matter accumulation. Our result confirms the findings of Huang et al., (2008).However statistically lower values of aforesaid parameters were observed in the treatments where nitrogen applied at lower rate of 85 $\mathrm{kg} / \mathrm{ha}$ and the acute $\mathrm{N}$ deficient plots (control) as compare to other treatments where nitrogen content of plant tissue was maintained at higher level which reflect the high growth parameters.

Yield attributes viz. number of grains per spike, 1000 grains weight showed increasing trend with increasing rate of nitrogen (Table 1). Real time nitrogen management of $105 \mathrm{~kg}$ $\mathrm{N} /$ ha based on given LCC and SPAD threshold values was at par with recommended nitrogen management for all the given yield attributes. Trend was similar to what observed earlier in growth parameters like plant height, shoot per square meter, dry matter, and LAI. The final yield is a cumulative effect of growth, yield component, directly or indirectly contributing to yield. Thus statistically at par growth and yield component resulted no significant difference in grain yield in real time nitrogen management of $105 \mathrm{~kg} \quad \mathrm{~N} / \mathrm{ha}$ and recommended nitrogen management at fixed time. It could be attributed to better synchronization of $\mathrm{N}$ supply with crop $\mathrm{N}$ demand leading to higher $\mathrm{N}$ uptake, which improves photosynthetic rate leading higher growth and biomass production due to real time application of $\mathrm{N}$ based on LCC and SPAD threshold values. Higher photosynthetic rate at lower rate of nitrogen in LCC and SPAD based nitrogen management reflected in better reproductive growth too. Similar finding was also reported by Shukla $e t$ al., (2004) and Mathukia et al., (2014).

Study revealed a positive correlation between leaf chlorophyll content and chlorophyll meter (SPAD meter) reading. It observed that chlorophyll content and SPAD meter values 
did not differ significantly in the treatments where nitrogen applied at the rate of 105 $\mathrm{kg} / \mathrm{ha}$ based on given LCC and SPAD threshold value and recommended nitrogen management (Table 2).

However these treatments were significantly superior over the treatments where nitrogen applied at lower rate of $85 \mathrm{~kg} / \mathrm{ha}$ and the acute $\mathrm{N}$ deficient plots (control) as compare to other treatments where nitrogen content of plant tissue was maintained at higher level which reflect the high chlorophyll content and SPAD value. These results are in agreement with Sabo et al., 2002, Bojovic and Stojanovic.2005. Chlorophyll fluorescence
$\left(\mathrm{F}_{\mathrm{v}} / \mathrm{F}_{\mathrm{m}}\right.$ value $)$ which indirectly measures photosynthetic efficiency at 60 and 90 DAS were not found significantly differs in all the nitrogen management treatments except control. Although with increasing rate of nitrogen, $\mathrm{F}_{\mathrm{v}} / \mathrm{F}_{\mathrm{m}}$ was increased, the minimum $\mathrm{F}_{\mathrm{v}} / \mathrm{F}_{\mathrm{m}}$ was observed in control plot and maximum at was recorded in recommended nitrogen practice. The statistical difference in terms of maximal efficiency of PSII $\left(\mathrm{F}_{\mathrm{v}} / \mathrm{F}_{\mathrm{m}}\right)$ was observed only in the acute $\mathrm{N}$ deficient plots as other treatment did receive nitrogen either adequately at fixed time or on real time basis. In plants exposed to nitrogen deficiency lower values of $\mathrm{F}_{\mathrm{v}} / \mathrm{F}_{\mathrm{m}}$ were often found (Guidi et al., 1997).

Treatments chart for nitrogen fertilizer dose and application time

\begin{tabular}{|c|c|c|c|c|}
\hline \multirow[t]{2}{*}{ Treatments } & \multirow{2}{*}{$\begin{array}{c}\text { Total } \\
\text { nitrogen } \\
\text { (kg/ha) }\end{array}$} & \multicolumn{3}{|c|}{ Dose (kg/ha) and Application time } \\
\hline & & $\begin{array}{c}\text { First split } \\
\text { (Basal) }\end{array}$ & Second split & Third split \\
\hline Control (no N) & 0 & 0 & 0 & 0 \\
\hline Recommended N 150 & 150 & 50 & $\begin{array}{c}50(25 \mathrm{DAS} / \\
\mathrm{CRI})\end{array}$ & $\begin{array}{c}50 \text { (45 DAS/Maxi } \\
\text { tillering) }\end{array}$ \\
\hline$* 30 \mathrm{~kg} \mathrm{~N}$ at LCC 4 & 85 & 25 & $30(29 \mathrm{DAS})$ & $30(55 \mathrm{DAS})$ \\
\hline$* 40 \mathrm{~kg} \mathrm{~N}$ at LCC 4 & 105 & 25 & $40(29 \mathrm{DAS})$ & 40 (57 DAS) \\
\hline$* 30 \mathrm{~kg} \mathrm{~N}$ at LCC 5 & 85 & 25 & $30(25$ DAS $)$ & $30(45$ DAS $)$ \\
\hline$* 40 \mathrm{~kg} \mathrm{~N}$ at LCC 5 & 105 & 25 & $40(25 \mathrm{DAS})$ & $40(47 \mathrm{DAS})$ \\
\hline$* 30 \mathrm{~kg} \mathrm{~N}$ at SPAD 40 & 85 & 25 & $30(25$ DAS $)$ & $30(46$ DAS $)$ \\
\hline$* 40 \mathrm{~kg} \mathrm{~N}$ at SPAD 40 & 105 & 25 & $40(27 \mathrm{DAS})$ & 40 (49 DAS) \\
\hline$* 30 \mathrm{~kg} \mathrm{~N}$ at SPAD 35 & 85 & 25 & $30(32 \mathrm{DAS})$ & $30(56 \mathrm{DAS})$ \\
\hline$* 40 \mathrm{~kg} \mathrm{~N}$ at SPAD 35 & 105 & 25 & 40 (32DAS) & 40 (57 DAS) \\
\hline $\begin{array}{l}* 30 \mathrm{Kg} \mathrm{N} \text { at } \mathrm{CRI}+30 \mathrm{~kg} \text { at } \\
\text { SPAD } 40\end{array}$ & 85 & 25 & $\begin{array}{c}30 \text { (25DAS/ } \\
\text { CRI) }\end{array}$ & $30(51 \mathrm{DAS})$ \\
\hline $\begin{array}{l}* 40 \mathrm{Kg} \mathrm{N} \text { at } \mathrm{CRI}+40 \mathrm{~kg} \text { at } \\
\text { SPAD } 40\end{array}$ & 105 & 25 & $\begin{array}{c}40 \\
\text { (25DAS/CRI) }\end{array}$ & $40(51 \mathrm{DAS})$ \\
\hline
\end{tabular}

*25 kg N/ha was applied as basal 
Table.1 Effect of different nitrogen management treatments on growth, yield attributes and grain yield of wheat

\begin{tabular}{|c|c|c|c|c|c|c|c|c|c|c|c|c|}
\hline \multirow[t]{2}{*}{ Treatments } & \multirow{2}{*}{$\begin{array}{c}\text { Total } \\
\text { dose of } \mathrm{N} \\
\text { (kg/ha) }\end{array}$} & \multicolumn{2}{|c|}{$\begin{array}{l}\text { plant height } \\
\text { (cm) }\end{array}$} & \multicolumn{2}{|c|}{$\begin{array}{c}\text { Shoot density } \\
\left(\text { Shoots } / \mathbf{m}^{2}\right)\end{array}$} & \multicolumn{2}{|c|}{$\begin{array}{c}\text { Dry matter } \\
\left(\mathrm{g} / \mathrm{m}^{2}\right)\end{array}$} & \multicolumn{2}{|c|}{$\begin{array}{c}\text { Leaf area } \\
\text { Index (LAI) }\end{array}$} & \multirow[t]{2}{*}{$\begin{array}{c}\text { No. of } \\
\text { grain/spike }\end{array}$} & \multirow{2}{*}{$\begin{array}{c}1000 \\
\text { grain } \\
\text { weight } \\
\text { (g) }\end{array}$} & \multirow{2}{*}{$\begin{array}{r}\text { Grain } \\
\text { yield } \\
\text { (t/ha) }\end{array}$} \\
\hline & & $\begin{array}{c}\text { 60 } \\
\text { DAS }\end{array}$ & $\begin{array}{c}90 \\
\text { DAS }\end{array}$ & $\begin{array}{c}\text { 60 } \\
\text { DAS }\end{array}$ & $\begin{array}{c}90 \\
\text { DAS }\end{array}$ & $\begin{array}{c}\text { 60 } \\
\text { DAS }\end{array}$ & $\begin{array}{c}90 \\
\text { DAS }\end{array}$ & $\begin{array}{c}\text { 60 } \\
\text { DAS }\end{array}$ & $\begin{array}{c}90 \\
\text { DAS }\end{array}$ & & & \\
\hline Control (no N) & 0 & 22.1 & 38.0 & 190 & 178 & 38 & 238 & 2.4 & 1.6 & 30.6 & 28.6 & 1.3 \\
\hline Recommended N & 150 & 37.3 & 93.8 & 432 & 413 & 182 & 700 & 4.1 & 2.9 & 49.2 & 46.4 & 4.3 \\
\hline $30 \mathrm{~kg}$ at $\mathrm{LCC} 4$ & 85 & 30.5 & 80.6 & 322 & 302 & 116 & 578 & 3.4 & 2.4 & 35.3 & 35.6 & 2.6 \\
\hline $40 \mathrm{~kg}$ at $\mathrm{LCC} 4$ & 105 & 35.1 & 90.6 & 413 & 395 & 160 & 660 & 3.9 & 2.5 & 47.1 & 44.0 & 3.8 \\
\hline $30 \mathrm{~kg}$ at LCC 5 & 85 & 32.6 & 80.9 & 350 & 330 & 120 & 581 & 3.5 & 2.5 & 36.3 & 36.0 & 2.7 \\
\hline $40 \mathrm{~kg}$ at $\mathrm{LCC} 5$ & 105 & 34.4 & 91.3 & 418 & 402 & 163 & 673 & 4.0 & 2.6 & 47.8 & 44.0 & 4.1 \\
\hline${ }^{*} 30 \mathrm{~kg}$ at SPAD 40 & 85 & 33.2 & 84.7 & 355 & 335 & 122 & 590 & 3.5 & 2.4 & 37.5 & 38.3 & 2.8 \\
\hline${ }^{*} 40 \mathrm{~kg}$ at SPAD 40 & 105 & 35.5 & 93.0 & 428 & 410 & 168 & 676 & 4.0 & 2.7 & 48.3 & 44.3 & 4.1 \\
\hline${ }^{*} 30 \mathrm{~kg}$ at SPAD 35 & 85 & 33.4 & 85.6 & 341 & 321 & 118 & 565 & 3.1 & 2.4 & 35.3 & 35.6 & 2.6 \\
\hline${ }^{*} 40 \mathrm{~kg}$ at SPAD 35 & 105 & 35.1 & 91.2 & 417 & 398 & 162 & 664 & 4.0 & 2.6 & 47.6 & 43.4 & 3.9 \\
\hline $\begin{array}{c}30 \mathrm{Kg} \text { at CRI+30 } \\
\mathrm{kg} \text { at SPAD } 40\end{array}$ & 85 & 35.5 & 84.6 & 360 & 335 & 124 & 585 & 3.6 & 2.4 & 37.3 & 36.0 & 2.7 \\
\hline $\begin{array}{c}40 \mathrm{Kg} \text { at CRI+40 } \\
\mathrm{kg} \text { at SPAD } 40\end{array}$ & 105 & 36.0 & 92.0 & 419 & 402 & 169 & 674 & 4.0 & 2.7 & 47.8 & 44.2 & 4.0 \\
\hline SEm. \pm & & 1.7 & 2.6 & 11 & 11 & 11 & 22 & 0.3 & 0.2 & 2.3 & 2.8 & 2.0 \\
\hline $\mathrm{CD}(\mathrm{P}=0.05)$ & & 5.1 & 7.7 & 32 & 34 & 32 & 65 & 0.8 & 0.6 & 6.8 & 8.3 & 0.6 \\
\hline
\end{tabular}

$* 25 \mathrm{~kg} \mathrm{~N} / \mathrm{ha}$ was applied as basal, recommended N $150 \mathrm{~kg} \mathrm{~N} / \mathrm{ha}$ in 3 equal splits, i.e. $50 \mathrm{~kg} / \mathrm{ha}$ as basal, $50 \mathrm{~kg} / \mathrm{ha}$ at crown-root initiation (CRI) stage and $50 \mathrm{~kg} / \mathrm{ha}$ at maximum tillering stage

Table.2 Effect of different nitrogen management treatments on chlorophyll content, SPAD meter and Fv/Fm value and total nitrogen uptake

\begin{tabular}{|c|c|c|c|c|c|c|c|c|}
\hline \multirow[t]{2}{*}{ Treatments } & \multirow{2}{*}{$\begin{array}{c}\text { Total dose } \\
\text { of } \mathbf{N} \\
(\mathrm{kg} / \mathrm{ha})\end{array}$} & \multicolumn{2}{|c|}{$\begin{array}{c}\text { Chlorophyll } \\
\text { content (mg/g) }\end{array}$} & \multicolumn{2}{|c|}{ SPAD meter } & \multicolumn{2}{|c|}{$\mathbf{F}_{\mathrm{v}} / \mathbf{F}_{\mathrm{m}}$} & \multirow{2}{*}{$\begin{array}{l}\text { Total N } \\
\text { uptake } \\
\text { (kg/ha) }\end{array}$} \\
\hline & & 60 DAS & 90 DAS & 60 DAS & 90 DAS & 60 DAS & 90 DAS & \\
\hline Control (no N) & 0 & 1.30 & 1.22 & 33.7 & 30.8 & 0.54 & 0.53 & 25 \\
\hline Recommended N & 150 & 1.75 & 1.66 & 38.4 & 36.4 & 0.80 & 0.78 & 106 \\
\hline${ }^{*} 30 \mathrm{~kg}$ at LCC 4 & 85 & 1.52 & 1.43 & 34.3 & 32.0 & 0.72 & 0.69 & 59 \\
\hline $40 \mathrm{~kg}$ at LCC 4 & 105 & 1.80 & 1.71 & 39.4 & 38.9 & 0.78 & 0.74 & 98 \\
\hline $30 \mathrm{~kg}$ at LCC 5 & 85 & 1.56 & 1.47 & 35.0 & 32.3 & 0.73 & 0.72 & 64 \\
\hline $40 \mathrm{~kg}$ at LCC 5 & 105 & 1.84 & 1.83 & 42.1 & 40.6 & 0.79 & 0.76 & 101 \\
\hline $\begin{array}{c}\text { *30 kg at SPAD } \\
40\end{array}$ & 85 & 1.57 & 1.49 & 40.5 & 40.0 & 0.75 & 0.73 & 68 \\
\hline $\begin{array}{c}\text { * } 40 \mathrm{~kg} \text { at SPAD } \\
40\end{array}$ & 105 & 1.88 & 1.83 & 42.3 & 41.1 & 0.79 & 0.78 & 105 \\
\hline $\begin{array}{c}\text { * } 30 \mathrm{~kg} \text { at SPAD } \\
35\end{array}$ & 85 & 1.52 & 1.43 & 35.7 & 32.6 & 0.72 & 0.70 & 66 \\
\hline $\begin{array}{c}40 \mathrm{~kg} \text { at SPAD } \\
35\end{array}$ & 105 & 1.80 & 1.71 & 40.4 & 39.3 & 0.78 & 0.76 & 98 \\
\hline $\begin{array}{c}30 \mathrm{Kg} \text { at } \mathrm{CRI}+30 \\
\mathrm{~kg} \text { at SPAD } 40\end{array}$ & 85 & 1.56 & 1.48 & 39.3 & 40.0 & 0.73 & 0.71 & 63 \\
\hline $\begin{array}{l}{ }^{*} 40 \mathrm{Kg} \text { at } \mathrm{CRI}+40 \\
\mathrm{~kg} \text { at SPAD } 40\end{array}$ & 105 & 1.81 & 1.76 & 41.3 & 40.1 & 0.77 & 0.75 & 104 \\
\hline SEm. \pm & & 0.08 & 0.06 & 1.5 & 1.4 & 0.02 & 0.02 & 5 \\
\hline $\mathrm{CD}(\mathrm{P}=0.05)$ & & 0.24 & 0.19 & 4.4 & 4.1 & 0.06 & 0.08 & 16 \\
\hline
\end{tabular}

$* 25 \mathrm{~kg} \mathrm{~N} / \mathrm{ha}$ was applied as basal, recommended N $150 \mathrm{~kg} \mathrm{~N} / \mathrm{ha}$ in 3 equal splits, i.e. $50 \mathrm{~kg} / \mathrm{ha}$ as basal, $50 \mathrm{~kg} / \mathrm{ha}$ at crown-root initiation (CRI) stage and $50 \mathrm{~kg} / \mathrm{ha}$ at maximum tillering stage 
Fig.1 Agronomic efficiency ( $\mathrm{kg}$ grain yield increased per $\mathrm{kg} \mathrm{N}$ applied), recovery efficiency (\%), net returns $\left(\times 10^{3} \square\right)$ and benefit: cost ratio as influenced by different treatments
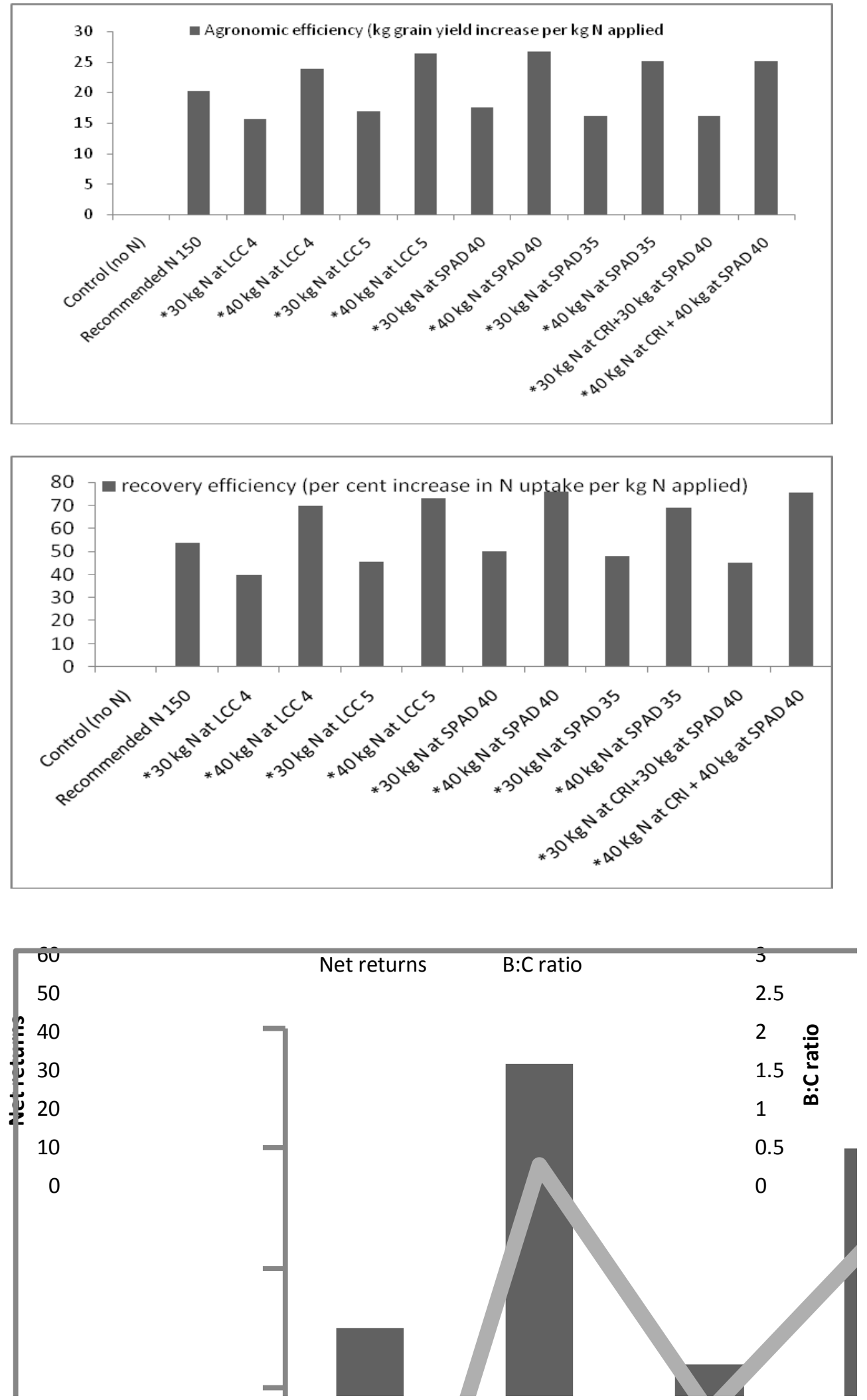
Increasing trend of total nitrogen uptake was obtained with increasing rate of nitrogen application. Although total nitrogen uptake was maximum in recommended management practice, it was at par with treatments of applied total nitrogen at the rate of $105 \mathrm{~kg}$ N/ha based on given LCC and SPAD threshold values. In recommended application of nitrogen, crop took $106.1 \mathrm{~kg}$ of nitrogen which indicated that crop required much quantity of nitrogen for full growth and development. The same quantity can be obtained by crop when real time nitrogen management was followed but for that about $105 \mathrm{~kg} \mathrm{~N} / \mathrm{ha}$ had to be provided. There was significant difference for the total nitrogen uptake in $105 \mathrm{~kg} \mathrm{~N} / \mathrm{ha}$ application compared to applied nitrogen at the rate of $85 \mathrm{~kg} \mathrm{~N} / \mathrm{ha}$ and control. Maiti and Das (2006) also reported that the total $\mathrm{N}$ uptake was directly proportional to total $\mathrm{N}$ rates and the highest $\mathrm{N}$ uptake was observed in the fixed-scheduling treatment where highest level of $\mathrm{N}$, i.e., 150 $\mathrm{kg} \mathrm{N} \mathrm{ha}{ }^{-1}$ was applied in three splits. The total $\mathrm{N}$ uptake in SPAD and LCC-based $\mathrm{N}$ plot was slightly lower compared to the highest level of fixed-timing $\mathrm{N}$ plot, which might be attributed to less $\mathrm{N}$ application through the use of SPAD and LCC which also preserved $\mathrm{N}$ without any yield reduction. Bisht (2000) reported that nitrogen application increased the nitrogen content in grain and straw and there by high total nitrogen uptake by wheat crop in SPAD based treatment.

Nitrogen use efficiency in terms of agronomic efficiency i.e., $\mathrm{kg}$ grain yield increased per $\mathrm{kg}$ nitrogen applied and recovery efficiency i.e., per cent increased in $\mathrm{N}$ uptake per $\mathrm{kg} \mathrm{N}$ applied both were declined with the increasing rate of nitrogen application from 105 to $150 \mathrm{~kg} / \mathrm{ha}$. There was maximum an increase of 24.3 and 22.1 per cent in agronomic efficiency and recovery efficiency respectively when total $105 \mathrm{~kg} / \mathrm{ha} \mathrm{N}$ applied at SPAD 40 over recommended $\mathrm{N}$ management treatment. High value of nitrogen use efficiency in terms of agronomic efficiency and recovery efficiency reported in LCC and SPAD based treatments might have been attributed to better and timely availability of nitrogen for their utilization by plant as judged from higher and statistically similar grain nitrogen content, total nitrogen uptake, grain yield with lesser $\mathrm{N}$ application by using SPAD and LCC besides saving of 30 $\mathrm{kg} \mathrm{N} / \mathrm{ha}$. Thus, study revealed efficient utilization of fertilizer with saving of $45 \mathrm{~kg}$ $\mathrm{N} / \mathrm{ha}$ (30 per cent). These findings are in line with Khurana et al., (2008) and Singh et al., (2007).

Maximum numerical value of net returns and $\mathrm{B}$ : $\mathrm{C}$ ratio was recorded in recommended practice but it was almost similar to $105 \mathrm{~kg} / \mathrm{ha}$ $\mathrm{N}$ applied in LCC and SPAD based treatments. In all the SPAD and LCC based treatments high net returns and $\mathrm{B}$ : $\mathrm{C}$ ratio was obtained where nitrogen applied at $105 \mathrm{~kg} / \mathrm{ha}$ could be attributed to statistically similar grain yield and low input cost observed in case of SPAD and LCC based treatment. There was only Rs 3292 higher net return was obtained in the recommended practice compared to next best treatment, i.e. application of $25 \mathrm{~kg} \mathrm{~N}$ as basal $+40 \mathrm{~kg}$ at SPAD 40 yet environmental benefit and fertilizer saving will be huge (Fig. 1).

From the research study, It is concluded that application of nitrogen at lower rate of $105 \mathrm{~kg}$ $\mathrm{N} / \mathrm{ha}(25 \mathrm{~kg} \mathrm{~N} / \mathrm{ha}$ as basal and two splits of 40 $\mathrm{kg}$ nitrogen applied based on LCC and SPAD threshold value 4,5 and 35,40 ) aid in utilized nitrogen more efficiently with the saving of 30 per cent or $45 \mathrm{~kg}$ /ha nitrogen without any significant decrement in growth and grain yield compared to recommended nitrogen management practice of $150 \mathrm{~kg} / \mathrm{ha}$. Also if $105 \mathrm{~kg} \mathrm{~N} / \mathrm{ha}$ is applied as basal at the rate of $25 \mathrm{~kg} / \mathrm{ha}, 40 \mathrm{~kg} / \mathrm{ha}$ at CRI stage and followed by single split of $40 \mathrm{~kg} / \mathrm{ha}$ whenever LCC or 
SPAD falls below 4, 5 and 35, 40 respectively produces same result as that of two splits of $40 \mathrm{~kg} / \mathrm{ha}$ in LCC and SPAD based treatments. Thus both tools can be used as efficient ones to determine the time and amount of nitrogen application to the crop and helping farmer to utilize the fertilizer nitrogen efficiently and optimally.

\section{References}

Bisht, T.S. 2000. Studies on nitrogen management in wheat through chlorophyll meter. M.Sc. Ag (Agron.) thesis, Govind Ballabh Pant University of Agriculture amd Technology, Pantnagar, India.

Bojovic,B., and Stojanovic, J. 2005. Chlorophyll and carotenoid content in wheat cultivars as a function of mineral nutrition. Archives of Biological Sciences. 57: 283-290.

Cassman, K. G., S. Peng, D. C. Olk, J. K. Ladha, W. Reichardt, A. Dobermann, and Singh, U. 1998. Opportunities for increased nitrogen use efficiency from improved resource management in irrigated rice systems. Field Crops Res.56:7-38.

Guidi, L., G. Lorefice, A. Pardossi, F. Malorgio, F. Tognoni and Soldatini, G. F. 1997.Growth and photosynthesis of Lycopersicon esculentum (L.) plants as affected by nitrogen deficiency. Biologia Plantarum. 40: 235-244.

Huang, J., F. He, K. Cui, J. Roland, B.X. Buresh, W. Gong and Peng, S. 2008. Determination of optimal nitrogen rate for rice varieties using a chlorophyll meter. Field Crops Research. 105 (1,2): 70-80.

Jackson, M. L. 1958. Soil Chemical Analysis. Constable and Co Ltd., London, pp.141151

Khurana, H. S., S. B. Phillips, B. Singh, M. M. Alley, A. Dobermann, A.S. Sidhu,
Y. Singh and Peng, S. 2008. Agronomic and economic evaluation of site-specific nutrient management for irrigated wheat in northwest India. Nutrient Cycling in Agro ecosystem. 82: 15-31

Krupnik, T.J., J. Six, J.K. Ladha, M.J. Paine and van, K. C. 2004. An assessment of fertilizer nitrogen recovery by grain crops. (In) Agriculture and the Nitrogen Cycle: Assessing the Impacts of Fertilizer Use on Food Production and the Environment (SCOPE 65), Mosier Syers, J.K. and Freney, J.R. et al., (Eds) pp. 193-208. Island Press, London.

Maiti, D., and Das, D.K. 2006. Management of nitrogen through the use of leaf colour chart (LCC) and soil plant analysis development (SPAD) in wheat under irrigated ecosystem. Arch. Agron. Soil Sci. 52(1): 105-112.

Mathukia, R. K., K. D. Gajera and Mathukia, P. R. 2014. Validation of leaf colour chart for real time nitrogen management in wheat. Journal of Dynamics in Agricultural Research. 1(1): 1-4.

Sabo, M., T. Teklic and Vidovic, I. 2002. Photosynthetic productivity of two winter wheat varieties (Triticum aestivum L.). Rostlinna Vybroba. 48: 80-86.

Shukla, A. K., J. K. Ladha, V. K. Singh, B.S. Dwivedi, V. Balsubhramanian, R. K. Gupta, S. K. Sharma, Y. Singh, H. Pathak, P.S. Pandey, A. T. Padre and Yadav, R. T. 2004. Calibrating the leaf color chart for nitrogen management in different genotypes of rice and wheat in a systems perspective. Agronomy Journal. 96(6): 1606-1621.

Singh, M., V.P. Singh and Sammi, R. K. 2001. Effect of integrated use of fertilizer nitrogen and farmyard manure or green manure on transformation of $\mathrm{N}, \mathrm{K}$ and $\mathrm{S}$ and productivity of ricewheat system on a vertisol. J. Ind. Soc. Soil Sci. 49: 430 - 435. 
Singh, B., Y. Singh, J. K. Ladha, K. F. Bronson, V. Balasubramanian, J. Singh and Khind, C. S. 2002. Chlorophyll meter and leaf color chart based nitrogen management for rice and wheat in northwestern India. Agronomy Journal. 94: 821-829.

Singh, V., Y. Singh, B. Singh, R. K. Gupta, J.
Singh, J. K. Ladha and Balasubramanian, V. 2007. Performance of site specific nitrogen management for irrigated transplanted rice in northwestern India. Archives of Agronomy and Soil Science. 53:567579.

\section{How to cite this article:}

Reena, V.C. Dhyani, Sumit Chaturvedi and Himansu Sekhar Gouda. 2017. Growth, Yield and Nitrogen Use Efficiency in Wheat as Influenced by Leaf Colour Chart and Chlorophyll Meter Based Nitrogen Management. Int.J.Curr.Microbiol.App.Sci. 6(12): 1696-1704. doi: https://doi.org/10.20546/ijcmas.2017.612.191 